\section{Observations on rutting behaviour of Hangul Deer Cervus elaphus hanglu (Cetartiodactyla: Cervidae) in Dachigam National Park, Kashmir, India}

\author{
Bilal A. Bhat ${ }^{1}$, G. Mustafa Shah ${ }^{2}$, Ulfat Jan ${ }^{2}$, \\ Fayaz A. Ahangar ${ }^{2} \&$ M.F. Fazili ${ }^{2}$ \\ 1,2 P.G. Department of Zoology, University of Kashmir, Srinagar \\ 190006, India \\ Email: bilalwildlife@yahoo.co.in ${ }^{1}$
}

Here we present an observation on the rutting behaviour of the nationally threatened population of Red Deer in Kashmir, Cervus elaphus hanglu, commonly known as Hangul, in the Dachigam National Park (DNP).

\section{Study Area}

Dachigam National Park, $\left(34^{\circ} 05^{\prime}-34^{\circ} 12^{\prime} \mathrm{N} \& 74^{\circ} 54^{\prime}-\right.$ $75^{\circ} \mathrm{O} 9^{\prime} \mathrm{E}$ ) is situated $21 \mathrm{~km}$ northeast of Srinagar (Fig. 1). Roughly rectangular, the park has a total area of $141 \mathrm{~km}^{2}$. It is approximately $24 \mathrm{~km}$ in length and $6 \mathrm{~km}$ in breadth ranging in altitude from $1700 \mathrm{~m}$ to $4000 \mathrm{~m}$. It comprises of a more or less contiguous range of mountains, except in the west where it has been artificially fenced along the borders of the national park. The average climate of Dachigam is sub-mediterranean Marked by the beginning of fir forest, the park is generally divided into the lower $\left(26 \mathrm{~km}^{2}\right)$ and upper Dachigam, $\left(115 \mathrm{~km}^{2}\right)$.

\section{Methods}

Observations of hangul deer were made along eight transects (I-VIII) having a total length of $24.5 \mathrm{~km}$ in lower Dachigam. In addition, the lower Dachigam slopes were scanned from specific vantage points and watch towers using $10 x 50$ field binoculars. The slopes facing the north and the south were scanned alternately. Observations were recorded

Date of online publication 26 June 2009

ISSN 0974-7907 (online) | 0974-7893 (print)

Editor: L.A.K. Singh

\section{Manuscript details:}

Ms \# 02125

Received 24 January 2009

Final received 10 April 2009

Finally accepted 03 June 2009

Citation: Bhat, B.A., G.M. Shah, U. Jan, F.A. Ahangar \& M.F. Fazili (2009) Observations on rutting behaviour of Hangul Deer Cervus elaphus hanglu (Cetartiodactyla: Cervidae) in Dachigam National Park, Kashmir, India. Journal of Threatened Taxa 1(6): 355-357.

Copyright: ( Bilal A. Bhat, G. Mustafa Shah, Ulfat Jan, Fayaz A. Ahangar \& M.F. Fazili 2009. Creative Commons Attribution 3.0 Unported License. JoTT allows unrestricted use of this article in any medium for non-profit purposes, reproduction and distribution by providing adequate credit to the authors and the source of publication.

Acknowledgements: Sincere thanks are due to DST, GOI for providing financial assistance under the research project entitled "Bioecology of Hangul deer (Cervus elaphus hanglu Wagner) and its relationship with the predators at Dachigam National Park, Kashmir". Authors are thankful to Nazir Ahmad Malik and Gh. Mohammad Sheikh (Department of Wildlife) for assisting in the field.

\section{OPEN AGCESS | FREE DOWNLOAD}

for brief periods only when the animals were visible on open slopes, without disruption due to dense canopy. Field data pertaining to behaviour, herd size and composition were collected on data sheets and classified into three groups: stags, hinds and fawns. The anthropogenic activities in the rutting grounds were also recorded.

\section{Results and Discussion}

The rutting or reproductive activity began by late September and extended up to the first week of November. The mature stags, which may be found in small groups in summer, became intolerant of each other and separated. The rut took place in the main valley and along the slopes of lower Dachigam (Fig.1). The peak of the rut was from October 9 to 20 after which it faded out. This observation is similar to that of Kurt (1977) and Schaller (1969), who reported peak of rut in the second week of October.

The most conspicuous feature of rut was the reverberating resonant roaring calls by stags. During this the stag raises its muzzle slightly upward, and with partially open mouth emits the sound at high intensity. The roar is a loud resonant bugle beginning harshly and ending on a clear deep note dropping progressively in pitch.

An estimated 8-11 stags were present in rutting grounds. The stags were either solitary or had at the most 4 hinds with them. Out of 34 to 47 hangul observed, 8-11 were stags, 21-30 were hinds and 4-6 were fawns. A total of 24 breeding herds were seen, the size of which varied from 2-5 and included one large stag, one or more hinds, and occasionally they were with a fawn. On several occasions there were one or two young stags in the herd. The largest number of hinds seen with a stag was four. Solitary hinds were seen on seven occasions.

The roar by a stag often resulted in response to roars from one or more stags and then there is an exchange of roars back and forth. This roaring continued at times for about 40-43 minutes. The stags roared more frequently and spent more time standing at such times of the day when the hinds were feeding. Stags with hinds roared more and tended to spend less time feeding on days when the nearest rutting stag was close by.

The calls were mostly heard in the study area between the dawn shortly after $0600 \mathrm{hr}$ and the dusk till $1830 \mathrm{hr}$, which is in accordance with Kurt (1977) and Schaller (1969). Roaring reached daily peaks between 0700 and $0900 \mathrm{hr}$, and again between 1640 and $1830 \mathrm{hr}$, but did continue even after. Counting of calls was discontinued after 1900hr (Fig. 2). Only large stags with more than eight points were observed to roar. These mature stags had dark-brown swollen necks in contrast to the grey-brown slender necks of the young stags. From September 23 onwards the calls were heard only occasionally. The frequency of the calls varied considerably from day to day and appeared to be related to the weather condition. On warm and clear mornings stags were heard roaring less often than on rainy cool mornings. Higher numbers of calls were heard on cloudy days than on clear days.

After 20 October, the number and intensity of the roars decreased considerably indicating that the peak of rut had passed. Occasional roars were heard up to 09 November. It 
Table 1: Average numbers of deer observed during rutting

\begin{tabular}{llll}
\hline Year & Stag & Hind & Fawn \\
\hline 2005 & 11 & 30 & 4 \\
2006 & 8 & 22 & 6 \\
2007 & 9 & 21 & 4 \\
\hline
\end{tabular}

was also found to be related to topographic aspects. Roaring started earlier on the south facing slopes where the sun shines earlier than the north facing slopes. The roaring intensity was found to be directly related to the density of the stags in a particular area. A call by one stag frequently stimulated one or more stags to respond, sometimes for about 40-45 minutes. Since roaring tended to occur more or less at the same time intervals, it could be considered an attempt to acoustic territorial demarcation. When a rutting male was approached by a number of young males at the same time, he always chased away the oldest or the best developed stag first. The chase-away strategy adopted by a mature stag is to steadily walk towards the rival stag that may be young or is seen with hinds.

Stags in rut were seen to trash their antlers frequently against bushes and trees. This activity was seen to continue at a stretch for 5-10 minutes. Sometimes, this behavior was more pronounced when another stag was in the close vicinity. Many small plants were thus damaged by such stags. Marks of fraying and trashing were generally easily found and represented by bark stripped more or less completely around the vertical stems of woody plants. Occasionally signs were also found on grass and soil. Prunus sp., Rosa sp., Berberis lycium, Indigofera haterantha and Cotoneaster sp. were the most common species used for antlertrashing in the broad leaved forest and the grass covered slopes. Marks of fraying were observed from 32.5 up to $180 \mathrm{~cm}$ above the ground level, with the average ranging from 30 to $90 \mathrm{~cm}$. On Prunus sp., fraying marks were seen from a height of $60 \mathrm{~cm}$ up to $173 \mathrm{~cm}$. For Berberis it was from $33 \mathrm{~cm}$ onwards and for Rosa sp. it ranged from $50 \mathrm{~cm}$ up to $145 \mathrm{~cm}$. According to Kurt (1977) antler trashing was a means of communication to warn other males.

Courtship behavior was observed on six occasions and got disturbed on a couple of occasions due to vehicular noise from the $6 \mathrm{~km}$ road to VIP lodge at Draphama in lower Dachigam. The stags stayed close to the hinds. When the hind walked, the stag followed. When the hind browsed, the stag stopped and remained standing erect behind or parallel to the hind. On 11 October 2006, a stag and a hind were observed from $0810 \mathrm{hr}$ till $1825 \mathrm{hr}$. They remained together all the day resting most of the time. The stag made a number of attempts to mount, but was not successful. At $1741 \mathrm{hr}$ the stag went round the female, placed his chin on her rump and then mounted. The stag mounted twice in quick succession. The first one was of the longest duration, of about 6 seconds followed by the 2 nd, which was of 3 seconds duration. The number of calls that this stag gave throughout this observation period was 43. Only mature stags ( 8 tined and above) were observed to be involved in courtship.

Overall rutting was disturbed by daily convoys across the hangul habitat, and other interferences like livestock grazing, grass and fuel extraction by locals. Gruisen (1983), Shah et al. (2008) and Bhat (2008) recorded several anthropogenic disturbances impairing the normal behaviour of wild animals

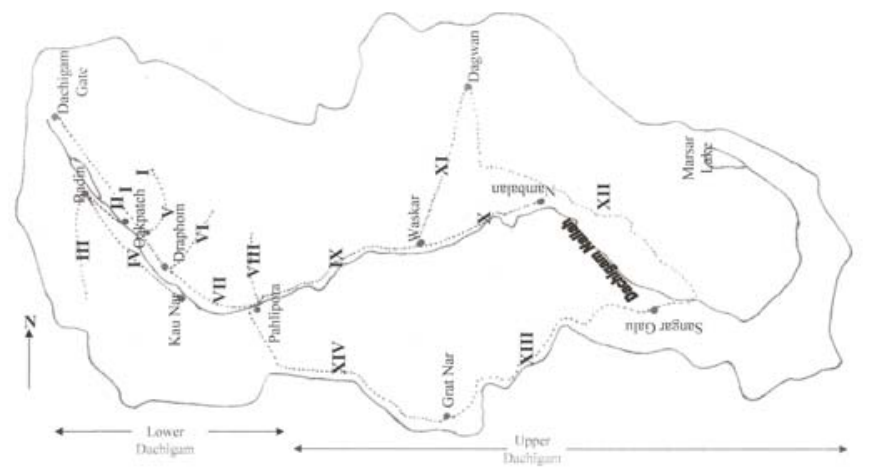

Figure1. Dachigam National Park

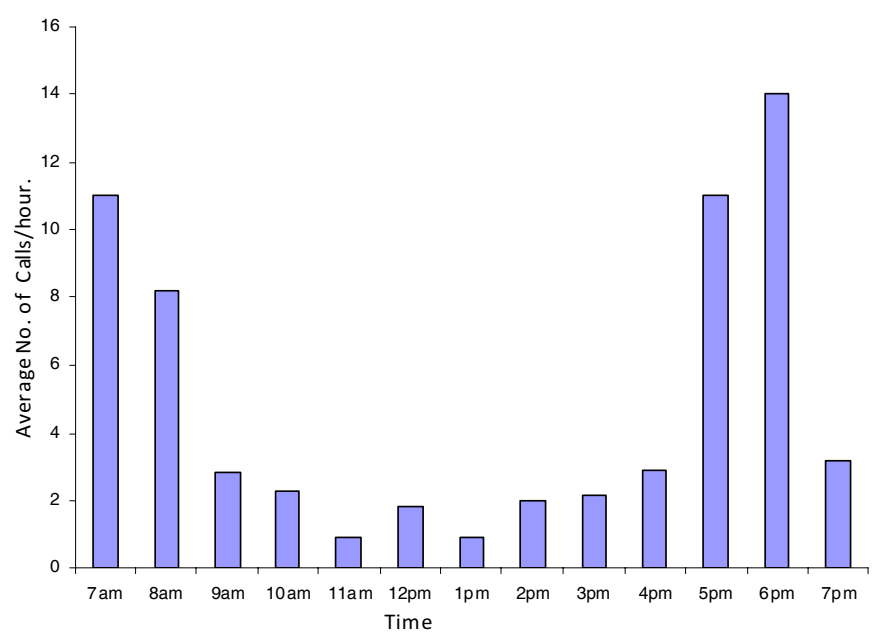

Figure 2. Average number of rutting calls/hour

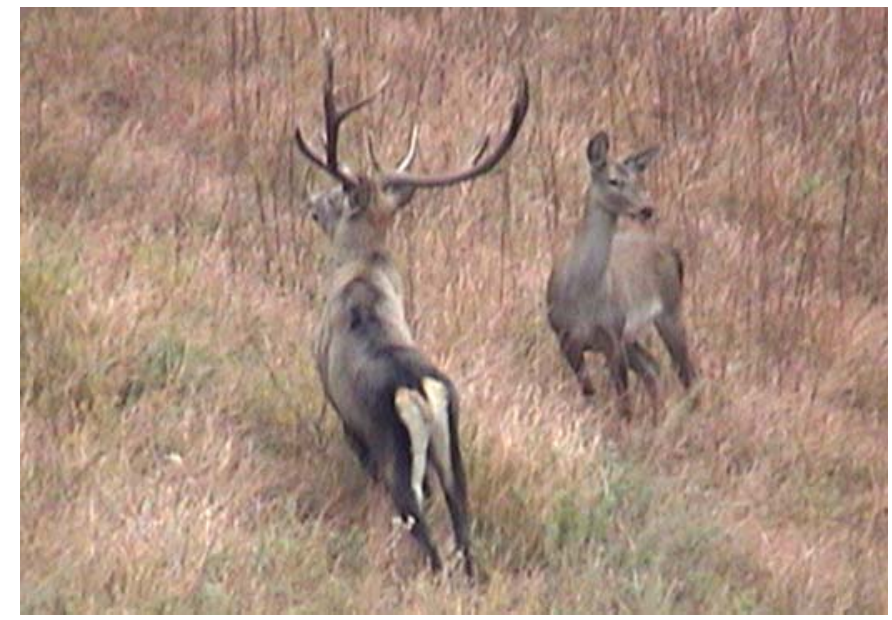

Image 1. Breeding pair

including hangul in DNP. Kurt (1977) has reported the clear cut difference in the behaviour of rutting stags in disturbed and undisturbed areas.

\section{Recommendation}

Restriction of vehicular traffic, to lower Dachigam during rutting season of hangul should be enforced and fully implemented. 


\section{References}

Bhat B.A. (2008). Ecological studies of hangul deer (Cervus elaphus hanglu Wagner) with reference to its conservation at Dachigam National Park, Kashmir, India. PhD Thesis, Department of Zoology, University of Kashmir, Srinagar.

Gruisen, J.V. (1983). The hangul, Dachigam's endangered deer. Sanctuary Asia 3: 114-131.

Kurt, F. (1977). Kashmir deer (Cervus elaphus hangulu) in Dachigam. Working meeting of the IUCN Deer Specialist Group, Longview, September, (1977) 43pp. mimeo.

Schaller, G.B. (1969). Observations on the hangul or Kashmir Stag
(Cervus elaphus hanglu, Wagner). Journal of Bombay Natural History Society 66(1): 1-7.

Shah G.M., U. Jan, B.A. Bhat, J.A. Wani, F.A. Ahangar \& M. Bashir (2008). Problems Encountered in the Management and Conservation of Hangul deer (Cervus elaphus hanglu Wagner) at Dachigam National Park, Kashmir. Science for Better Tomorrow, 2008: 547-554. Editors: M. Z. Chishti and Fayaz Ahmad. 